\title{
EFFECT OF IRRIGATION BY SALINE GROUND WATER ON THE GROWTH OF SOME CONIFER SEEDLINGS: MORTALITY, GROWTH, BIOMASS AND PHYSICAL WOOD PROPERTIES
}

(Received :16.8.2006)

\author{
By \\ M. H. Khamis and H. H. Hammad* \\ Timber Trees Department, Horticulture Research Institute, Agriculture Research Center, Giza, Sabahia \\ Horticulture Research Station, Alexandria-*Horticulture Research Institute, Giza, Egypt
}

\begin{abstract}
An open field trial for 2-year-old seedlings of bald-cypress (Taxodium distichum Rich.), calabrian pine (Pinus brutia Tenore) and cypress (Cupressus sempervirens L.) seedlings was applied from April, 2004 to November, 2005 in King- Mariut, south-west of Alexandria. Response of these conifer seedlings to irrigation regime of saline underground water $\left(6.36 \mathrm{dS} \mathrm{m}^{-1}\right)$ was studied in a large polyethylene bag containing sandy loam soil. Irrigation treatments were applied as: tap water (control), twice saline water followed by one time tap water ( $2 / 1$ cycle), four times saline water followed by one time tap water $(4 / 1$ cycle) and totally saline water (Stressed). Irrigation treatments were applied to maintain the double-fold of field capacity after 45 days from transplanting date the irrigated tested every third day.

The results showed that mortality increased with increasing saline/ fresh water cycles. Conversely, all the vegetative growth parameters and biomass components of these conifer seedlings decreased significantly with increasing the cycling of saline/ fresh water. However, significantly minimum both height and diameter increments, number of first order-branch, fresh and dry biomasses of leaves and stem were obtained where saline water was applied as continuous irrigation treatment (stressed). Likewise wood density was decreased by increasing saline irrigation cycle whereas there was a slight decrease in wood fiber length with the increase of saline water cycle. Pine seedlings seem to be statistically more efficient to tolerate saline ground water than cypress after two years period. However, bald-cypress seedlings were highly- sensitive to irrigation by $6.36 \mathrm{dSm}^{-1}$ saline ground water to the extent that all seedlings died under the entire used irrigation cycles.
\end{abstract}

Key words: biomass,conifer,saline ground water. Physical wood properties,

\section{INTRODUCTION}

The use of poor quality water for irrigation has the potential to save considerable quantities of good quality water for higher priority uses. Otherwise, King- Mariut, an recreation area located in the south west of Alexandria, is suffered from lack of irrigation water for private properties. The present investigation attempts to find further ways for overcoming the water shortage problem, where the existing water resources are less than the water demand. Although aquifer ground water is an alternative source to overcome this problem, unfortunately the ground water of this area mostly is salty. FAO, (1992) stated that saline water irrigation has been successfully practiced for extended periods of time in many countries including Egypt. Fresh water is required to flush out accumulated salts (leaching) to make the soil suitable for tree growth. Therefore, alternation of fresh and saline ground water, is an irrigation technique that can conserve ground water resources and minimize the possible long-term negative effects of saline water on tree growth and soils. Certain tree species tolerate salinity is better than others so many scientists evaluated the influence of salinity on tree species (Khan and Ismail, 1985 and Marcar et al., 2000).

For most soils, a leaching would result in maintaining a salt balance at recommended levels. As the leaching increases, salt concentrations should be decrease as more water passes through 
the root zone. Glenn, (1997) explained that if the quantity of fresh water for leaching through the soil is too low to remove salts, the soil salt content will increase and the yield may decrease. This decrease in yield occurred as the plant must redirect additional energy (osmotic stress) from growing to extracting pure water from the saline water in its root zone. Injury resulting from the presence of soil salts is caused by differences in osmotic potential values between the tree and the soil solution. A specific ion effect associated with specific salt ion such as $\mathrm{Na}$ and $\mathrm{Cl}$ or a combination of these two effects (Dirr, 1976). High osmotic pressure decreases the availability of soil water causing moisture stress within the plant. Therefore, Spotts et al., (1972 and Button et al., (1977) concluded that the specific ion effect involves movement of ions as $\mathrm{Na}$ and $\mathrm{Cl}$ into plant cells where they adversely affect cell membrane stability and metabolism and high concentrations are toxic and may kill the cells. Soluble salts my reduce vegetative growth if they are in high enough concentration in irrigation water. Mainly, this effect is indirect by pulling moisture out of the roots and reducing the uptake of water and nutrients to affected plants. Accordingly, (Alden, 1980) mentioned that trees tolerate to soil salt accumulations are able to adapt to salt because they have the ability to: (1) absorb and conserve water under salt stress, (2) exclude salt ion uptake, or (3) physiologically tolerate in in the presence of the salt ion. For instance, Jarunee et al., (2003) suggest that the salt tolerance of Sesbania rostrata is associated with the ability of the shrub to translocate and sequester $\mathrm{Na}^{+}$and $\mathrm{Cl}^{-}$in the shoot cells.

The objective of this study was to assess the best cyclic practice of irrigation to improve and maintain use of the existing saline ground water resources in King-Mariut area in Alexandria.

\section{MATERIALS AND METHODS}

\subsection{Plant material}

A trial with different salinity treatments for two-year-old seedlings of bald-cypress (Taxodium distichum Rich.), calabrian pine (Pinus brutia Tenore) and cypress (Cupressus sempervirens L.) was applied within two seasons in a private nursery in King-Mariut ( $30^{\circ} 58.18^{`} \mathrm{~N}$; $\left.29^{\circ} 42.69^{\prime} \mathrm{E}\right)$, $50 \mathrm{Km}$ southwest of Alexandria. The substitutive irrigation source of this nursery is saline water from underground shallow aquifer where its analysis is tabulated in (Table 1). The depth of the irrigation aquifer is $25 \mathrm{~m}$ from the soil surface and the water is pumped up to the surface through a network of PVC pipes controlled by main valve. All seedlings were transplanted in (March 13, $2004)$ in large polyethylene bags $(50 \mathrm{~cm}$ diameter X $60 \mathrm{~cm}$ depth) containing sandy loam soil $(58,26$ and $16 \%$ of sand, loam and clay respectively) where its analysis of ions and cations is shown in (Table 2). Then, they were watered totally with tap water to reach the field capacity $(16.2 \mathrm{~g}$ water $100 \mathrm{~g}^{-1}$ dried soil) for 30 days before starting the treatments.

\subsection{Treatments}

Irrigation treatments were applied as: tap water (control), twice saline water followed by once tap water (2/1 cycle), four times saline water followed by once time tap water (4/1 cycle) and totally saline water (Stressed). All seedlings were irrigated to its double-fold of field capacity. The experimental design was a completely randomized split-plot with irrigation treatments as the main plot and species as the subplot in three replicates. Each replicate was represented by 3 seedlings therefore, 36 seedlings of each species were used.

\subsection{Measurements}

Mortality $\%$ was calculated for each treatment as well as, the number of first-order branch (number of main branches) of the seedlings were recorded at the end of experiment. Stem height and diameter above ground level of all seedlings were measured before the treatments (initial measuring) and two growing seasons afterwards (final measuring). The different meaing the increment of stem height and diameter above ground. Also, two random seedlings of each replicate were destructively harvested at the end of the second growing season (November 2005) then leaves, stems and roots biomass was determined. Subsequently these components were dried in the oven for 48 hours at $60^{\circ} \mathrm{C}$ for leaves and $80 \mathrm{C}^{\circ}$ for stems and roots. Also, some physical wood properties of the used conifer species were tested to evaluate its response to irrigation cycles by saline ground water. A sample of $3-\mathrm{cm}$ 
Table (1): Chemical analysis of the used tap and underground aquifer irrigation water.

\begin{tabular}{|c|c|c|c|c|c|c|c|c|c|c|}
\hline \multirow{2}{*}{$\begin{array}{c}\text { Irrigation } \\
\text { water quality }\end{array}$} & \multicolumn{4}{|c|}{ Soluble cations (mg l-1) } & \multicolumn{4}{|c|}{ Soluble anions $\left(\mathrm{mg} \mathrm{l}^{-1}\right)$} & \multirow[t]{2}{*}{ pH } & \multirow{2}{*}{$\begin{array}{c}\text { E.C. } \\
\text { dS m }^{-} \\
1\end{array}$} \\
\hline & $\mathrm{K}^{+}$ & $\mathrm{Na}^{+}$ & $\begin{array}{l}\mathrm{Mg} \\
+2\end{array}$ & $\mathrm{Ca}^{+2}$ & $\mathrm{SO}_{4}^{-2}$ & $\mathrm{Cl}^{-}$ & $\mathrm{HCO}_{3}^{-}$ & $\mathrm{CO}_{3}^{-2}$ & & \\
\hline Tap water & 0.12 & 1.45 & 1.30 & 1.64 & 0.16 & 1.58 & 2.77 & - & 7.50 & 0.48 \\
\hline $\begin{array}{l}\text { underground } \\
\text { water }\end{array}$ & 0.79 & 48.40 & 9.80 & 5.00 & 21.99 & 36.40 & 5.60 & - & 7.50 & 6.36 \\
\hline
\end{tabular}

Table (2): Chemical analysis of the planting soil.

\begin{tabular}{|c|c|c|c|c|c|c|c|c|c|c|}
\hline \multicolumn{4}{|c|}{ Soluble cations $\left(\mathrm{mg} \mathrm{l}^{-1}\right)$} & \multicolumn{4}{|c|}{ Soluble anions $\left(\mathrm{mg}^{-1}\right)$} & \multirow{2}{*}{$\begin{array}{c}\mathrm{CaCO}_{3} \\
\%\end{array}$} & \multirow[t]{2}{*}{ pH } & \multirow{2}{*}{$\begin{array}{c}\text { E.C. } \\
\mathrm{dS} \mathrm{m}^{-1}\end{array}$} \\
\hline $\mathrm{K}^{+}$ & $\mathrm{Na}^{+}$ & $\mathrm{Mg}^{+2}$ & $\mathrm{Ca}^{+2}$ & $\mathrm{SO}_{4}^{-2}$ & $\mathrm{Cl}^{-}$ & $\mathrm{HCO}_{3}^{-}$ & $\mathrm{CO}_{3}^{-2}$ & & & \\
\hline 0.305 & 2.04 & 0.24 & 1.1 & 0.935 & 1.3 & 1.45 & - & 32.5 & 8.0 & 0.35 \\
\hline
\end{tabular}

Table (3): Effect of irrigation by saline ground water on mortality and firstorder branch number of three conifer seedlings after two seasons

(April,2004 to November 2005).

\begin{tabular}{|l|c|c|c|c|c|c|c|c|}
\hline \multirow{2}{*}{ Treatment } & \multicolumn{4}{|c|}{ Mortality (\%) } & \multicolumn{4}{c|}{ No. first-order branch } \\
\cline { 2 - 9 } & $\begin{array}{c}\text { Bald- } \\
\text { cypress }\end{array}$ & Cypress & Pine & Mean & Bald-cypress & Cypress & Pine & Mean \\
\hline Control & $0.00 \mathrm{e}$ & $0.00 \mathrm{e}$ & $0.00 \mathrm{e}$ & $0.00 \mathrm{~d}$ & $37.00 \mathrm{c}$ & $94.0 \mathrm{a}$ & $16.0 \mathrm{~d}$ & $55.0 \mathrm{a}$ \\
\hline $2 / 1$ cycle & $100 \mathrm{a}$ & $22.22 \mathrm{~d}$ & $0.00 \mathrm{e}$ & $40.74 \mathrm{c}$ & - & $78.5 \mathrm{~b}$ & $11.0 \mathrm{de}$ & $45.8 \mathrm{~b}$ \\
\hline $4 / 1$ cycle & $100 \mathrm{a}$ & $44.44 \mathrm{c}$ & $0.00 \mathrm{e}$ & $48.15 \mathrm{~b}$ & - & $75.5 \mathrm{bc}$ & $8.0 \mathrm{ef}$ & $41.8 \mathrm{c}$ \\
\hline Stressed & $100 \mathrm{a}$ & $77.78 \mathrm{~b}$ & $0.00 \mathrm{e}$ & $57.41 \mathrm{a}$ & - & $73.0 \mathrm{c}$ & $5.5 \mathrm{f}$ & $39.3 \mathrm{c}$ \\
\hline Mean & $75.00 \mathrm{x}$ & $34.72 \mathrm{y}$ & $0.00 \mathrm{z}$ & & & $80.8 \mathrm{x}$ & $10.1 \mathrm{y}$ & \\
\hline
\end{tabular}

Means followed by a similar letter within a column $(\mathrm{a}, \mathrm{b})$ or row $(\mathrm{x}, \mathrm{y})$ are not significantly

different at the probability 0.05 by Duncan's Multiple Range Test.

Table (4): Effect of irrigation by saline ground water on both height and diameter increments of three conifer seedlings after two seasons (April,2004 to November 2005) .

\begin{tabular}{|c|c|c|c|c|c|c|c|c|}
\hline \multirow{2}{*}{$\begin{array}{c}\text { Treatm } \\
\text { ent }\end{array}$} & \multicolumn{4}{|c|}{ Height increment (\%) } & \multicolumn{4}{|c|}{ Diameter increment (\%) } \\
\hline & $\begin{array}{c}\text { Bald- } \\
\text { cypress }\end{array}$ & Cypress & Pine & Mean & $\begin{array}{c}\text { Bald- } \\
\text { cypress }\end{array}$ & Cypress & Pine & Mean \\
\hline Control & 67.23 & $62.36 \mathrm{a}$ & $31.28 \mathrm{c}$ & $46.82 \mathrm{a}$ & 92.56 & $78.29 \mathrm{e}$ & $134.07 \mathrm{a}$ & $106.18 \mathrm{a}$ \\
\hline $\begin{array}{l}2 / 1 \\
\text { cycle }\end{array}$ & - & $50.89 \mathrm{~b}$ & $24.02 \mathrm{de}$ & $37.46 \mathrm{~b}$ & - & $78.09 \mathrm{e}$ & $122.22 \mathrm{c}$ & $100.16 b$ \\
\hline $\begin{array}{l}4 / 1 \\
\text { cycle }\end{array}$ & - & $28.51 \mathrm{~cd}$ & $15.55 f$ & $22.03 \mathrm{c}$ & - & $62.79 f$ & $128.89 b$ & $95.84 \mathrm{c}$ \\
\hline Stressed & - & $21.06 \mathrm{e}$ & $11.31 \mathrm{f}$ & $16.19 \mathrm{~d}$ & - & $24.03 \mathrm{~g}$ & $88.15 \mathrm{~d}$ & $56.09 \mathrm{~d}$ \\
\hline Mean & & $40.71 x$ & $20.54 y$ & & & $60.80 y$ & $118.33 x$ & \\
\hline
\end{tabular}


was cut from each stem at the soil surface. The sample was divided into two further samples, the first 2-cm was used to determine the wood density and the remained $1-\mathrm{cm}$ to determine the fiber length. Wood density was determined based on the fresh volume and oven- dry weight according to the American Standard Testing Method (ASTM D-2395, 1989). For fiber length measurement, the samples were portioned into small segments, having radial and tangential dimension of $2 \times 5$ $\mathrm{mm}$, respectively. Segments were macerated in a 1:1 (v:v) solution of acetic acid glacial and 30\% hydrogen peroxide at $60^{\circ} \mathrm{C}$ for 48 hours, then rinsed several times with distilled water (Franklin, 1964). For each sample, a drop of macerated tissue was placed on a microscope slide, stained with Safrinin dye, and covered. The slide was placed in a slide holder and projected onto a screen. Fifty whole fibers per sample were measured to the nearest $1 \mathrm{~mm}$.

Since bald-cypress seedlings completely failed to grow at all salinity treatment (2/1), (1/4) (stressed) then the data of this species were terminated from the statistical analysis but the data of control of this species was exhibited only. Data were examined by analysis of variance (ANOVA) and means were compared by Duncan's Multiple Range Test using CoStat statistic software (CoStat, 1990).

\section{RESULTS AND DISCUSSION \\ 3.1. Effect on mortality}

Irrigation with saline underground water had a significant effect on mortality of the planted conifer tree seedlings (Table 3). Mortality percentage increased with increasing the saline water frequency from ( $2 / 1$ cycle) up to (stressed). Nearly $57 \%$ of mortality was achieved by (stressed) treatment, regardless of the seedling species, which was the highest mortality percentage. The treatment (4/1 cycle) had about $48 \%$ mortality overall while ( $2 / 1$ cycle) had about $41 \%$ and finally, the control treatment had zero $\%$ of mortality. On the other hand, bald cypress appeared to have the higher significant mortality percentage followed by cypress that recorded nearly 75.00 and $34.72 \%$ of mortality, respectively (Table 3). Complete mortality was recorded in bald cypress seedlings except those irrigated with tap water (control) while 100\% of pine seedlings survived in all irrigation treatments. Otherwise, cypress seedlings had inconsistent mortality responses to saline irrigation water varying from $77.78 \%$ when treated with (stressed) treatment to zero\% when supplied with only tap water (control).

The analysis of variance revealed a significant interaction between saline irrigation treatments and the conifer species on mortality percentage due to the differential response of the seedlings. Bald-cypress seedlings under all treatments of saline ground water had the highest percentage of mortality $(100 \%)$ that reflected its high sensitivity to any saline irrigation level. Conversely, pine seedlings had the lowest mortality percentage $(0.00 \%)$ under all treatments meaning that it is a high saline-tolerated species. Generally, with the progressive increase in the saline irrigation cycles from $(2 / 1$ cycle) to (stressed) treatment, there was a gradual increase in the mortality percentage of cypress seedlings; that means it is a moderate saline-tolerated species.

The main explanation of the $100 \%$ mortality of bald-cypress possibly that it is a deciduous conifer species which looses its leaves, the main accumulator of salts thus, the accumulations of salts during the dormant season will not be toxic to the plant. Munns, (1993) concluded that continuous salt accumulation combined with limited production of new leaf volume could lead to earlier build up of excess toxic levels of salt. This might further accelerate the onset of leaf senescence and necrosis. These results are in parallel with (Pezeshki, 1990) who subjected Taxodium distichum (bald--cypress) seedlings to $51 \mathrm{~mol} / \mathrm{m}^{3}$ of salinity concentration. Thereafter, he indicated that in general, bald-cypress was salt-sensitive probably due to its relative inability to exclude ions or effectively compartmentalize them in cell vacuoles. Moreover, an elucidation of increasing the mortality percentage of most (stressed) treatment of cypress seedlings, may be the presence of high amounts of soluble salts in the soil that reduces the amount of water available to the plant. As salts increase in the soil water, the energy expended by a plant to extract water must also increase, even though the soil moisture tension remains the same. In essence, salts decrease the total available water in the soil profile (Scherer et al., 1996). Subsequently the plant begins to suffer, then welts or dies according to its sensitivity. Therefore for low resistanre species, (Choudhary et al., 2003) concluded that photo-inhibition was the main factor responsible for drastic reduction in net photosynthesis rate and coupled with a toxic effect of salt ions on cellular metabolism made the survival of the plants impossible under high salinity. Also, tolerance of pine seedlings to all saline treatments is 
concurrent with Jarunee et al., (2003) on Sesbania rostrata. Furthermore, the clarification of that is possibly the seedlings have a salt tolerance determinant important for the regulation of $\mathrm{Na}^{+}$ and $\mathrm{K}^{+}$homeostasis in the plants as pyridoxal-5phosphatethat (Huazhong et al., 2002) that modulating the activities of ion transporters and/ or they activate choline biosynthesis (Zhonglin et al., 2002) that contributes to tolerance of salt stress.

\subsection{Effect on vegetative growth}

Statistical analysis indicated that there were strongly significant differences among the saline irrigation water treatment and tree species on vegetative growth Tables $(3 \& 4)$. Results showed that both (stressed) and (4/1 cycle) were the most in appropriate irrigation frequencies that minimized the first-order branch numbers of the tested species by 28.6 and $24.0 \%$, respectively compared with the control. Whereas, the $(2 / 1$ cycle) reduced the first-order branch number by $16.7 \%$ only compared with the control treatment. According to the seedling species, Table (3) illustrated that cypress had the highest first-order branch number ( 80.8 branches) ,while pine had 10.1 branches. The mean values in Table (3) cleared a significant interaction between saline irrigation treatments and conifer species on the first-order branch number where the cypress seedlings grown under tap water irrigation had recorded the highest first-order branch number that gradually decreased with increasing saline cycle from (2/1 cycle) to (stressed). The minimum first-order branch number was obtained with pine seedlings irrigated by (stressed) treatment. These effects are mainly due to the inherent properties of the seedlings species.

The results in Table (4) indicate that the effect of saline irrigation on height increment was much suppressed under (stressed) followed by $(4 / 1$ cycle) then $(2 / 1$ cycle $)$ treatments that recorded $16.19,22.03$ and $37.46 \%$, respectively as compared to the control which recorded 46.82 $\%$ of height increment. Furthermore, cypress seedlings recorded the highest significant stem increment $(40.71 \%)$ compaved with pine seedlings that recorded $20.54 \%$. According to the interaction effect between saline irrigation treatments and conifer species on height increment, it is noticeable that both cypress grew $(62.36 \%)$ or more under irrigation with tap water (control) than others. Conversely, all pine seedlings irrigated with (stressed and 4/1 cycle) had the lowest height increment where the other treatments had intermediate values (Table 4).
Diameter increment varied strongly depending on the saline/fresh water irrigation cycle and seedling species (Table 4). Effect of saline irrigation treatments on diameter increment had a similar trend which observed in the height increment. All seedlings irrigated by (stressed) treatment were the thinner followed by that treated by $(4 / 1$ cycle) then, those irrigated by $(2 / 1$ cycle $)$ which were $56.09,95.84$ and $100.16 \%$ comparing with the seedlings irrigated by tap water 106.18. The mean diameter increment of pine seedlings irrigated with saline ground water was $118.33 \%$ which was almost twice as cypress seedlings. Concerning the interaction effect of the tested conifer species within saline irrigation treatments on the diameter increment, it is evident that pine species under tap water irrigation (control) was superior that recorded $134.07 \%$ of thickness than other treatments while the cypress seedlings irrigated by stressed treatment recorded the lowest value furthermore. The other treatments had intermediate values (Table 4).

Similarly, (Hamlet and Morris, 1996; Wang et al., 1997 and Croser et al., 2001) on four Eucalyptus species and Atriplex prostrata, respectively, reported that they exhibit significant reduction in height, diameter growth and the width of the cortex and vascular tissues under saline conditions. The reduction of vegetative growth under saline water treatments could be attributed to the decline in the content of endogenous gibberellins and indole acetic acid hormones which are required for both shoot elongation and cambial growth (Zheng, 2002). Also, the large differences in first-order branch number between the three conifer tree species may be due to the inherent differences in morphology of these species. Otherwise, the significant differences in stem height and diameter increments between pine, cypress and bald-cypress are probably caused by differences in their tolerance to salt. Eckstein et al. (1978) concluded that after exposure to salinity, the xylem incremens in salttolerant Salix clones are wider with fewer vessels and more fibers and rays per unit area than in saltsensitive clones.

\subsection{Effect on biomass}

The data in Table (5) suggested that biomass allocations of the three conifer species had significant reduction under the saline ground water treatments. There was a slight significant reduction in leaves fresh weight of the three conifer seedlings when irrigated with saline ground water whereas the ( $2 / 1$ cycle), $(4 / 1$ cycle) and (stressed) treatments minimized the leaves 
fresh biomass by $6.7,12.0$ and $21.7 \%$, respectively as compared with the control that recorded the highest fresh leaves biomass (197.58 g seedling $\left.{ }^{-1}\right)$. Pine had the highest significant leaves fresh weight followed by cypress (203.90 and $151.28 \mathrm{~g}$ seedling $^{-1}$ ), respectively. On the other hand, the leaves fresh biomass of baldcypress recorded $115.00 \mathrm{~g}$ seedling ${ }^{-1}$ under irrigation with tap water. Likewise, leaves dry weights had also slight differences when irrigated with the saline treatments. The (stressed) treatment investigated the highest reduction in leaves dry weight $(36.7 \%)$ followed by ( $4 / 1$ cycle) and $(2 / 1$ cycle) treatments which reduced the leaves dry weights by 14.5 and $13.6 \%$, respectively less than the control. The three conifer species were differed significantly whereas, bald-cypress seedlings recorded the lowest weight of dry leaves $\left(43.15 \mathrm{~g}\right.$ seedling $\left.^{-1}\right)$ under tap water irrigation followed by cypress $\left(60.96 \mathrm{~g} \mathrm{seedling}^{-1}\right)$ then pine (120.63 $\mathrm{g}$ seedling ${ }^{-}$ $\left.{ }^{1}\right)$. Regarding the interaction effect between irrigation saline cycles and the three conifer species, was noticed that the magnitude of leaves biomasses (fresh and dry) were obtained by the pine seedlings irrigated with tap water followed by that irrigated with $(2 / 1$ cycle $)>(4 / 1$ cycle $)$. On the contrary, the lowest leaves biomass attained by cypress seedlings under (stressed) treatment whereas, other treatments had intermediate values.

The data in Table (5) revealed that stem fresh and dry weights had approximately, the same trend when irrigated with saline ground water. The (stressed) treatment had the lowest stem fresh weight followed by $(4 / 1$ cycle) then (2/1 cycle) which recorded 40.1, 21.2 and $1.6 \%$ less than the control. The stressed treatment had the lowest dry weight of stem by the same order that recorded 29.1, 14.2 and $11.1 \%$ less than the control. Furthermore, pine seedlings had significantly the highest mean of stem fresh and dry weights (138.89 and $88.30 \mathrm{~g}$ seedling ${ }^{-1}$, respectively) subsequent by cypress (95.66 and $64.80 \mathrm{~g}$ seedling $^{-1}$, respectively). The stem biomass achieved by the interaction of both cypress and pine species among the saline irrigation treatments was varied significantly where the magnitude stem fresh weights were detected in pine species under control and (2/1 cycle) treatments (160.55 and $156.90 \mathrm{~g}$ seedling ${ }^{-1}$, respectively) while the least fresh weights were identified with cypress seedlings under (stressed) irrigation cycle $\left(50.55 \mathrm{~g}^{2}\right.$ seedling $\left.{ }^{-1}\right)$ on the other hand, the remaining treatments had intermediate values.
Similarly, Table (5) exhibited that roots fresh and dry biomasses of the tested conifers had the same trend when treated with different irrigation cycles. The (stressed) cycle significantly had the highest negative effect on root biomasses where decreased both fresh and dry weights by 27.29 and $26.60 \%$, respectively less than control. Both (4/1) and (2/1) cycles which had the same significant level that decreased the fresh biomass by 21.57 and $22.20 \%$ as well as, dry biomass by 18.11 and $15.07 \%$ less than the control,. Moreover, pine seedlings significantly showed the highest fresh and dry biomass of roots (287.90 and $67.80 \mathrm{~g}^{2}$ seedling ${ }^{-1}$ ) followed by cypress that allocated150.91 and $42.56 \mathrm{~g}$ seedling $^{-1}$ respectively. As regard to the interaction effect of irrigation saline cycles and conifer species, it is evident that the bulky fresh and dry roots ( 334.50 and $83.63 \mathrm{~g}$ seedling $^{-1} \mathrm{~g}$ seedling ${ }^{-1}$, respectively) were allocated by pine seedlings treated with stressed cycle, conversely the tiny fresh and dry roots (53.50 and $11.24 \mathrm{~g}$ seedling ${ }^{-1}$, respectively) were allocated by cypress species under stressed irrigation cycle. The other treatments had an intermediate values. These results are concurrent with the finding of Wang et al., (1997) that Atriplex prostrata Boucher, a facultative halophyte, exhibits significant reduction in biomass under saline conditions. Also, with Croser et al., (2001) who concluded that the emergence of Pinus banksiana seedlings was the least affected by salinity as compared with other two boreal forest conifers, and at certain salinity concentrations, emergence even appeared to be stimulated by the presence of salt. An increase in salt levels caused a corresponding reduction in seedling weight. The reduction of biomass among the saline water treatments is probably due to the decrease in photosynthesis activity (Afroz et al., 2005). Otherwise, the increase in pine biomasses more than cypress and bald-cypress species could be explained that pine is a more resistance species under irrigation with saline water. Townsend and Kwolek, 1987; (Neumann, (1997) and Croser et al., (2001) cited that the plants of increased salinity resistante are expected to maintain higher rates of growth than less resistance plants under equivalent levels of salinity.

Figure (1) demonstrates that irrigation by saline ground water had significant effect on root: shoot ratio of cypress and pine seedlings. The (4/1) and stressed cycles decreased root: shoot ratio of cypress seedlings by 1.5 and 2.4-fold, respectively than the control. Contrarily, this ratio increased for pine seedlings by 1.2 and 1.4-fold 


\begin{tabular}{|c|c|c|c|c|c|c|c|c|}
\hline \multicolumn{9}{|c|}{$\begin{array}{l}\text { Table (5): Effect of irrigation by saline ground water on both leaves fresh and dry weights of } \\
\text { three conifer seedlings after two seasons (April,2004 to November 2005). }\end{array}$} \\
\hline \multirow[t]{2}{*}{ Treatment } & \multicolumn{4}{|c|}{ Fresh weight ( $\mathrm{g}$ seedling $\left.{ }^{-1}\right)$} & \multicolumn{4}{|c|}{ Dry weight $\left(\mathrm{g}^{2}\right.$ seedling $\left.{ }^{-1}\right)$} \\
\hline & $\begin{array}{c}\text { Bald- } \\
\text { cypress }\end{array}$ & Cypress & Pine & Mean & $\begin{array}{c}\text { Bald- } \\
\text { cypress }\end{array}$ & Cypress & Pine & Mean \\
\hline & \multicolumn{8}{|c|}{ Leaves biomass } \\
\hline Control & 115.00 & $165.55 \mathrm{~cd}$ & $229.60 \mathrm{a}$ & $197.58 \mathrm{a}$ & 43.15 & $80.05 \mathrm{bc}$ & $136.65 \mathrm{a}$ & $108.35 \mathrm{a}$ \\
\hline $2 / 1$ cycle & - & $163.65 \mathrm{bcd}$ & $204.90 \mathrm{ab}$ & $184.28 \mathrm{ab}$ & - & $66.10 \mathrm{~cd}$ & $121.20 \mathrm{ab}$ & $93.65 \mathrm{ab}$ \\
\hline 4/1 cycle & - & $153.05 \mathrm{de}$ & $194.75 a b c$ & $173.90 \mathrm{~b}$ & - & $66.65 \mathrm{~cd}$ & $118.60 \mathrm{ab}$ & $92.63 \mathrm{ab}$ \\
\hline Stressed & - & $122.88 \mathrm{e}$ & $186.35 \mathrm{bcd}$ & $154.62 \mathrm{c}$ & - & $31.05 \mathrm{~d}$ & $106.05 \mathrm{abc}$ & $68.55 \mathrm{~b}$ \\
\hline \multirow[t]{2}{*}{ Mean } & & $151.28 \mathrm{y}$ & $203.90 x$ & & & $60.96 \mathrm{y}$ & $120.63 x$ & \\
\hline & \multicolumn{8}{|c|}{ Stem biomass } \\
\hline Control & 112.75 & $117.90 \mathrm{~b}$ & $160.55 \mathrm{a}$ & $139.23 \mathrm{a}$ & 86.80 & $77.95 \mathrm{~b}$ & $99.25 \mathrm{a}$ & $88.60 \mathrm{a}$ \\
\hline $2 / 1$ cycle & - & $117.15 \mathrm{~b}$ & $156.90 \mathrm{a}$ & $137.03 \mathrm{a}$ & - & $63.60 \mathrm{~d}$ & $93.85 \mathrm{a}$ & $78.73 b$ \\
\hline 4/1 cycle & - & $97.05 \mathrm{~b}$ & $122.30 \mathrm{~b}$ & $109.68 \mathrm{~b}$ & - & $68.70 \mathrm{~cd}$ & $83.35 \mathrm{~b}$ & $76.03 \mathrm{~b}$ \\
\hline Stressed & - & $50.55 \mathrm{c}$ & $115.80 \mathrm{~b}$ & $83.18 \mathrm{c}$ & - & $49.45 \mathrm{e}$ & $76.75 \mathrm{bc}$ & $62.85 \mathrm{c}$ \\
\hline \multirow[t]{2}{*}{ Mean } & & $95.66 \mathrm{y}$ & $138.89 \mathrm{x}$ & & & $64.80 \mathrm{y}$ & $88.30 \mathrm{x}$ & \\
\hline & \multicolumn{8}{|c|}{ Roots biomass } \\
\hline Control & 339.30 & $235.60 \mathrm{~d}$ & $298.00 \mathrm{c}$ & $266.80 \mathrm{a}$ & 154.70 & $63.60 \mathrm{c}$ & $66.30 \mathrm{c}$ & $64.95 \mathrm{a}$ \\
\hline $2 / 1$ cycle & - & $211.75 \mathrm{e}$ & $203.40 \mathrm{e}$ & $207.58 \mathrm{~b}$ & - & $63.53 \mathrm{c}$ & $46.78 \mathrm{~d}$ & $55.16 \mathrm{~b}$ \\
\hline 4/1 cycle & - & $102.80 \mathrm{f}$ & $315.70 \mathrm{~b}$ & $209.25 b$ & - & $31.87 \mathrm{e}$ & $74.50 \mathrm{~b}$ & $53.19 \mathrm{~b}$ \\
\hline Stressed & - & $53.50 \mathrm{~g}$ & $334.50 \mathrm{a}$ & $194.00 \mathrm{c}$ & - & $11.24 \mathrm{f}$ & $83.63 a$ & $47.44 c$ \\
\hline Mean & & $150.91 \mathrm{y}$ & $287.90 \mathrm{x}$ & & & $42.56 y$ & $67.80 \mathrm{x}$ & \\
\hline
\end{tabular}

Table (6): Effect of irrigation by saline ground water on density and fiber length of three conifer seedlings after two seasons (April, 2004 to November 2005).

\begin{tabular}{|c|c|c|c|c|c|c|c|c|}
\hline \multirow[t]{2}{*}{ Treatment } & \multicolumn{4}{|c|}{ Density $\left(\mathrm{g} \mathrm{cm}^{-3}\right)$} & \multicolumn{4}{|c|}{ Fiber length (mm) } \\
\hline & Baldcypress & Cypress & Pine & Mean & $\begin{array}{c}\text { Baldcy } \\
\text { press }\end{array}$ & Cypress & Pine & Mean \\
\hline Control & 0.364 & $0.585 \mathrm{bc}$ & $0.629 a$ & $0.607 a$ & 1.69 & $1.28 b$ & $1.52 \mathrm{a}$ & $1.40 \mathrm{a}$ \\
\hline 2/1 cycle & - & $0.566 \mathrm{c}$ & $0.601 b$ & $0.584 b$ & - & $1.25 \mathrm{~b}$ & $1.19 \mathrm{~b}$ & $1.22 b$ \\
\hline 4/1 cycle & - & $0.498 \mathrm{~d}$ & $0.598 b$ & $0.536 \mathrm{c}$ & - & $1.24 \mathrm{~b}$ & $1.17 \mathrm{~b}$ & $1.21 \mathrm{~b}$ \\
\hline Stressed & - & $0.482 \mathrm{~d}$ & $0.574 \mathrm{c}$ & $0.528 \mathrm{~d}$ & - & $1.24 b$ & $1.20 \mathrm{~b}$ & $1.22 b$ \\
\hline Mean & & $0.533 y$ & $0.601 x$ & & & $1.25 \mathrm{x}$ & $1.27 \mathrm{x}$ & \\
\hline
\end{tabular}

Means followed by a similar letter within a column (a, b) or row (x, y) are not significantly

different at the probability 0.05 by Duncan's Multiple Range Test. 
whit $(4 / 1)$ and sirosed ofilos, ropasively itum inc ointrol, whorcan the (2i) cycke tad vice. wroa efloct in koth coniles specier with uninow: coplanasive $\mathrm{h}$ was otvicos that mont: shoot tatio of cypress spocoss wos in paralled wilk the main afled at the nooth hiomass of the experimast rather, pine species which hat an epposile ropoenc usder differene irrigation cycies meaning that pine seedlings allocated more soots biomans under (aresied) cycle (Table 5). Therefoec, this Acterior peoved that pine sprcies is more saltivictant than cypress.

This resuls is compathile with Wilvoe and Tilman (1905) as rootishoot ratios do not vary sipeificainily with habitat bet io vary ampes specien. Aiva, Cortum et al, (1958) ched that shoot thomh was more inhibined by $\mathrm{NaCl}$ than root growih. Thes, increasd rovertiont ratio appean so be an ahbptation to salinily, rovelting is

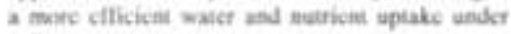
saline virces.

3.4. Effect as woed propertins

Takle $($ b) ahoms she effress of irrigation by saline evound waser, conifict specics and their interaction on both wowd schaity and fiter lenght

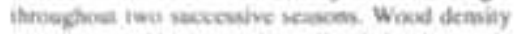
wa decreaned by iecreasing salim inigation cycle

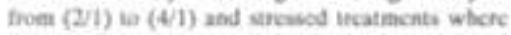
they miaimired the woond demity by $3 . \mathrm{K}, 11.7$ and 13.05 los than ite coeirol incatmenis. tespectively. Adetitiona- aly, pinc wedling bad segeni. facanily the demer wood (0.001 $\mathrm{f} \mathrm{cm}$ ) that cypress species $(0.533 \mathrm{~g}$ cin' $)$. Regardieg the interactives eflest, it is cobvices that pine seedling under tap waser imigation (control) bad ine Mcaviese wood density, On the othet hand, cypess scedling under both $(+1)$ and stresued saline water cocles had the lighiest wood density.

Thete was a slight decrease in wood fiber length with the increase of saline water cycle by 12.906 for both $(2 / 1)$ and stressed as well is by $13.6 \%$ for $(4 / 1)$ treatment less than control. On the other hand, the wood fiber length of the two conifer species (cypress and pine) had not significant differcnoss whercas itieir fiter loneth elongaind up in 1.25 and 1.27 mem, respectively. Acoosding to the internction

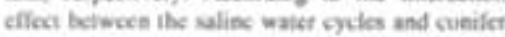
specics, pine scedling wood bad the kingest fiber length under tap water imigation (control) treatment rather than the other trcatments which had the same significant kevel.

These results ate in purallel with Calchpoole $\theta u l .,(2000)$ on eucalypts trees

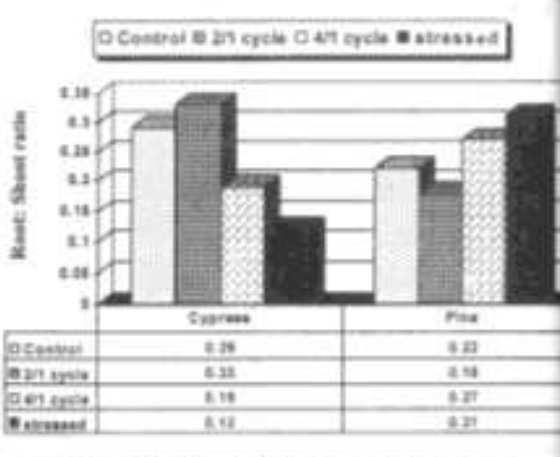

Fie. (1) Enfect of irrigatioe by salise groued -ater en reat: ahoet ratis of cypress and piae seedting afler twe seasoss ( April 2004 to Nevemater 2005).

planted in fwo siles as bave density of the plot receiving the moderate salinity irrigation water $\left(50\right.$ dS $\left.\mathrm{m}^{-1}\right)$ was $0.40-0.49 \mathrm{~g} \mathrm{~cm}^{-}$ differes from that of the plots receiving the highesel sulinity imigation water $\left(10\right.$ dS $\mathrm{m}^{-1}$ ) that reconded $0.4 \times-4.4 \mathrm{~W} \mathrm{~g} \mathrm{~cm}^{3}$ and the trah shaned water (0.48-0.52 $5 \mathrm{~cm}^{3}$ ) which may

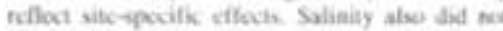
affor fither lingh hitwarn any of the plots ove the period of siady. In contrast, the demer wood at pinc scodlieg omputing wilh other onaiters may caplain that this is a vali-toletant specica

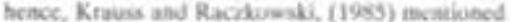
that resivanese of 14 limber troes lo effects of salinity (3.5\% scawater calieily) lemded ie increase wilh incriatits wood dstaiky.

Recommersdation

It is novmancrided that coevinually

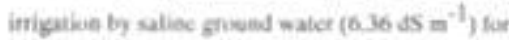
pine sectling os well ac, alismation syck (U) cycle) of salime and froh water for cypece

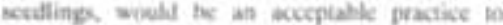
oheain a good growith in Kifs-Maruit atca.

\section{KFFRENCFS}

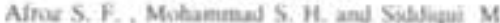
H. (20us). Eungonoun applicatina of ghtereilic wod Coenteracds the III effect of Sodium Colutidk in Mastand. Turkish J Binot, 20:221-26.

Aldem M. T, (twen) Idsatifyiog ines with

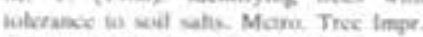
Alliance (METBdA) Proc, 3:24:32. 
American Society for Testing Materials, (1989). Standard test methods for specific gravity of wood and wood-base materials. ASTM D-2395-77. Philadelphia, PA

Button E. F., Rubins E. J., Woodward M. A. and Griffin, G. F. (1977). Effects of deicing salts and lead upon trees, shrubs and soils in Connecticut. National Tech. Info. Serv., Springfield, Va, 24 pp.

Catchpoole S. J, Downes G. and Read S. M (2000).The effect of salt on wood and fibre formation in eucalypts. Rural Industries Research \& Development Corporation, Publication No00/162. http://www.rirdc.gov.au/reports/HCC/00162sum.html.

Choudhary R., Joshi S., Gehlot H. S. and. Sankhla N. (2003). Chlorophyll fluorescence, photosynthesis and enzyme activities in Ber (Ziziphus rotundifolia) under salinity stress. In: Proc. Plant Growth Reg. Soc. Amer., 30.

CoStat Statistical Software, (1990). Co Stat Manual Revision 4.2, p. 271, Berkley, New York.

Croser C. ,Renault S., Franklin J. and Zwiazek J. (2001). The effect of salinity on the emergence and seedling growth of Picea mariana, Picea glauca, and Pinus banksiana. Environ Pollut. 115(1):9-16.

Dirr M. A., (1976). Selection of trees for tolerance to salt injury. J. Arbor., 2: 209- 216.

Eckstein D., Liese W. and Plossl J. (1978). Histometrische Untersuchungen zur unterschiedlichen Streusalztoleranz von Weiden (Salix spp.). Forstwiss. Centralbl. 97:335-341. (Cited after: Kozlowski T. T., (1997). Responses of woody plants to flooding and salinity. Tree Physiology Monograph No. (1).

FAO (1992). The Use of saline waters for crop production. Food and Agriculture Organization, Irrigation and Drainage Paper 48, Rome, Italy.

Franklin G. L. (1964). A rapid method for softening wood for microtome sectioning. Trop. Woods, Yale Univ. Sch. For. 88: 35-36.

Glenn E. (1997). An Analysis of the Demographic Effectiveness of Arizona County-toCounty Migration Streams, Yearbook, Association of Pacific Coast Geographers.

Gorham J., Jones R.G.W. and McDonell, E. (1985). Some mechanisms of salt tolerance in crop plants. Plant Soil 89:1540.

Hamlet A. and Morris J., (1996). Effects of salinity on the growth of four Eucalyptus species on irrigated sites in Northern Victoria, Report to the Trees for Profit Research Board, Centre for Forest Tree Technology, Melbourne.

Huazhong S., Xiong L., Stevenson B., Lu T. and Zhu, J. K. (2002). The Arabidopsis salt overly sensitive 4 Mutants Uncover a Critical Role for vitamin B6 in plant salt tolerance. The Plant Cell, 14: 575-588.

Jarunee J., kenji U. and Hiroshi, M. (2003). Differences in physiological responses to $\mathrm{NaCl}$ between salt-tolerant Sesbania rostrata Brem. \& Oberm. and non-tolerant Phaseolus vulgaris L. Weed Biology and Management, 3(1): 21- 28.

Khan A. R., and Ismail D. S. (1985). Growth of Azadirachta indica and Melia azedarach at coastal sand using highly saline water for irrigation. Pakistan J. of Bot. 1985, 17(2): 229-233.

Krauss A. and Raczkowski, J. (1985). Resistance of various wood species to the action of sea water substitute. Holzforschung und Holzverwertung. 1985, 37(4): 71-75. (Cited in: CAB Abstracts 1985 008-03199).

Marcar N. E.,. HossainM. A, Crawford D. F. and Nicholson A. T. (2000). Evaluation of tree establishment treatments on saline seeps near Underground aquiferington and Young in New South Wales jAustralian J. of Experimental Agriculture, 40 (1) : 99 106.

Munns R. (1993). Physiological processes limiting plant growth in saline soils: some dogmas and hypotheses. Plant, Cell and Environment, 16: 15-24.

Neumann P., (1997). Salinity resistance and plant growth revisited. .Plant Cell and Environment, 20: 1193- 1198.

Pezeshki S. R., (1990). A comparative study of the response of Taxodium distichum and Nyssa aquatica seedlings to soil an aerobiosis and salinity. Forest Ecology and Management. 33/34: 531-541.

Scherer T. F., Selig B. and Franzen, D. (1996). Soil, water and plant characteristics important to irrigation. North Dakota State Univ., NDSU Extension Service. EB-66, Feb. 1996, pp. 12. 
Spotts R., Altman J. and Staley, J. (1972). Soil salinity related to ponderosa pine tip-burn. Phyto-pathology, 62: 705- 708.

Townsend A. M. and Kwolek W. F. (1987). Relative susceptibility of thirteen pine species to sodium chloride spray. J. Arboric. 13:225- 228.

Wang L., Showalter A. M. and Ungar, I. A. (1997). Effect of salinity on growth, ion content, and cell Wall Chemistry in Atriplex prostrata (Chenopodiaceae). Physiology and Biochemistry, American J. of Botany, Vol. 84, 1247.

Wilson D.S. and Tilman D. (1995). Competitive responses of eight old-filed plant species in four environments. - Ecology, 76: 1169-1180.

Zheng H. Y., (2002). Vascular tissue differentiation and pattern formation in plants. Annual Review of Plant Biology, 53: $183-202$.

Zhonglin M., X. Wang X., Fu, Z. Dai, Y. Han;C. Ouyang; J. Bao, F. Hu Y and J. Li, J. (2002). Silencing of phosphor-ethanolamine $N$-Methyl transferase results in temperature-sensitive male sterility and salt hypersensitivity in Arabidopsis. The Plant Cell, 14: 2031-2043.

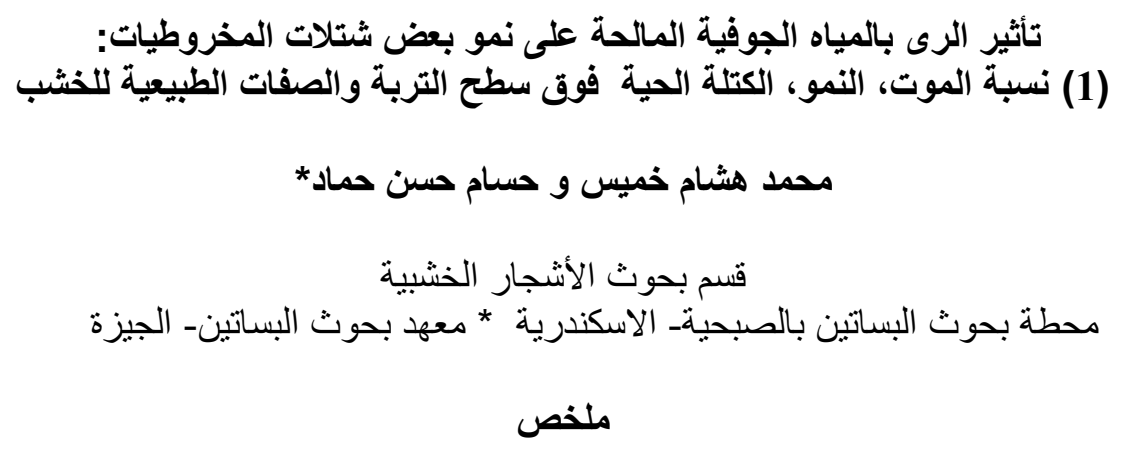

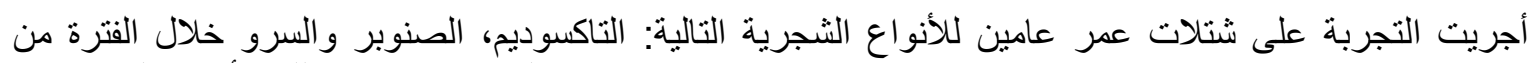

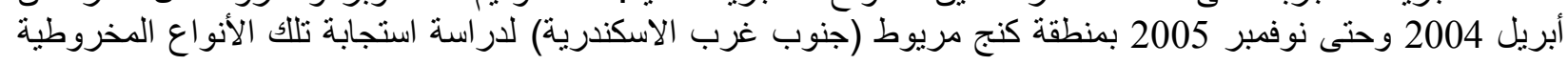
لنظام رى بمياه البئر الجوفى المالحة (حيث درجة التوصيل الكهربائلها= 6.36 لوفيل

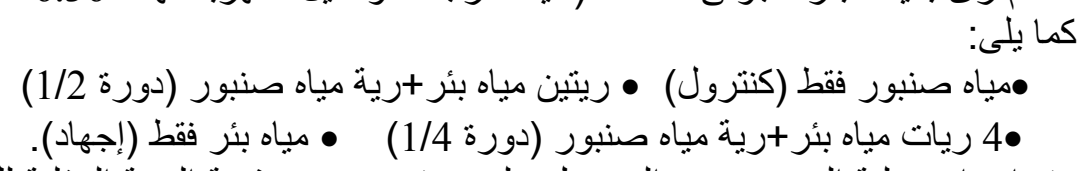

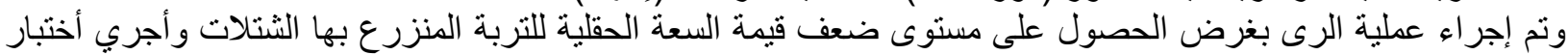

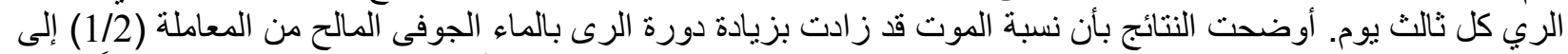

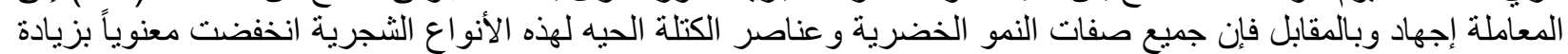

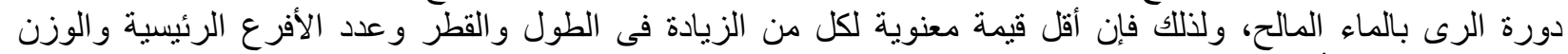

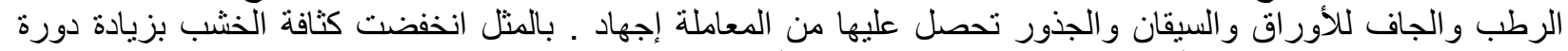

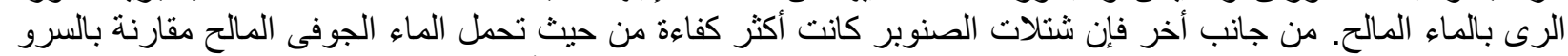

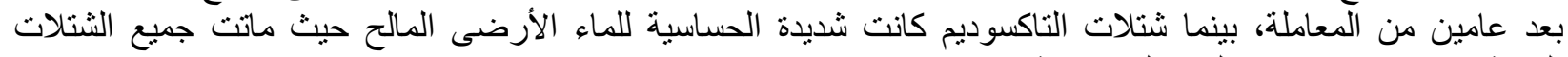
النامية تحت جميع دور من التعات الرى المستخدمة.

المجلة العلمية لكلية الزراعة - جامعة القاهرة - المجلد (58) العدد الأول ( 2007) :36- : 